\title{
Histone H1/MBP hydrolysing antibodies - novel potential marker in diagnosis of disease severity in systematic lupus erythematosus patients
}

\author{
Valentyna Chopyak ${ }^{1,2}$, Yaroslav Tolstiak ${ }^{1,2}$, Iryna Magoryvska ${ }^{3}$, Rostyslav Bilyy ${ }^{3}$, \\ Natalya Korniy ${ }^{4}$, Yuriy Kit ${ }^{3 *}$, Rostyslav Stoika ${ }^{3,4}$ \\ ${ }^{1}$ Lviv Medical Institute, Lviv, Ukraine \\ ${ }^{2}$ Danylo Halytsky Lviv National Medical University, Pekarska St., Lviv, Ukraine \\ ${ }^{3}$ Institute of Cell Biology, Lviv, Ukraine; *Corresponding Author: kit@,cellbiol.lviv.ua \\ ${ }^{4}$ Ivan Franko National University, Lviv, Ukraine
}

Received 30 July 2010; revised 5 August 2010; accepted 9 August 2010.

\begin{abstract}
Recently we have shown the presence of catalytically active IgGs, capable to cleave histone $\mathrm{H} 1$ and bovine myelin basic protein (MBP), in blood serum of SLE patients. Here we present data that demonstrate the correlation between a) proteolytic activity towards histone $\mathrm{H} 1$ and MBP of IgG-antibodies from blood serum of SLE patients and b) disease severity level in these patients. IgGs were isolated from blood serum by chromatography on protein G-sepharose. Commercial preparations of bovine myelin basic proteins (MBP) and calf thymus histone $\mathrm{H} 1$ were used as substrates. Analysis of the proteolytic activity showed that 16 of 38 IgG-preparations $(42,1 \%)$ obtained from blood serum of SLE patients were capable of cleaving both histone $\mathrm{H1}$ and MBP with different efficiency. It was revealed that the presence in blood serum of IgGs possessing proteolytic activity towards both histone $\mathrm{H} 1$ and bMBP closely correlates with manifestation of the disease severity in SLE patients.
\end{abstract}

Keywords: System Lupus Erythematosus; Proteolytic Activity; IgG-Antibodies; Disease Severity

\section{INTRODUCTION}

Systematic Lupus Erythematosus (SLE) is a chronic autoimmune disease characterized by dysfunction of $\mathrm{T}$ and B-lymphocytes and the dendritic cells, by production of the autoantibodies (auto-AB) to specific nuclear constituents. Its clinical manifestations are accompanied by the affection of connective tissues and small blood vessels of vital organs such as kidney, lung, heart and brain. For the past 30 years, great improvement in SLE prognosis was achieved, however the mortality and disability of SLE patients stays rather high [1,2]. A number of investigations revealed negative prognostic factors contracting SLE in childhood or humans after 50, tardiness of active therapy and development of such clinical manifestations as the affection of kidney, and central nervous system, complications in cardiovascular and respiratory systems, as well as high general severity of the disease [1,3-5]. The presence of auto-AB in blood serum of SLE patients is an important diagnostic factor [6]. Hereby, antinuclear auto-AB serves as molecular markers for the disease severity prognosis, as well as for its treatment efficiency [6,7]. Among antinuclear auto$\mathrm{AB}$ especially attract attention anti-DNA $\mathrm{AB}$ and antihistone $A B$ [8-10]. Possessing a cross reactivity to different protein autoantigens, these auto-AB can be involved in various mechanisms of pathogenesis, apoptosis of including immunocompetent cells, which is a decisive factor in the development of autoimmune syndrome and the disease in general. It is known that antiDNA AB of IgG classes of blood serum of SLE patients are also capable of hydrolyzing DNA and different types of RNA (having DNase and RNase activity) [10,11]. It was also found that DNA/RNA hydrolyzing AB (DNAabzymes) possess high cytotoxicity and their level in the blood serum of SLE patients correlates with the disease severity $[12,13]$. In contrast to anti-DNA AB, the role of anti-histone $\mathrm{AB}$ in the development of autoimmune processes in SLE patients is poorly studied. Recently, we have shown for the first time that in blood serum of SLE patients there are catalytic active IgG AB capable of hydrolyzing both histone H1 and MBP [14]. Antibodies 
possessing similar proteolytic activity were found in blood serum of multiple myeloma and multiple sclerosis patients $[15,16]$. We have shown that these proteolytically active $\mathrm{AB}$ can be classified as anti-histone auto-AB [17]. We also hypothesized that such AB could be responsible for the development of health disorders in SLE patients. We aimed to establish a correlation between the proteolytic activity of IgG-antibodies of blood serum towards histone $\mathrm{H} 1$ and myelin basic protein and the disease runing in SLE patients.

\section{EXPERIMENTAL}

\subsection{Patients}

Blood serum of 38 patients with SLE of different severity was used. SLE was diagnosed by criteria of the American Collegium of Rheumatologists (ACR, 1997) and stated in accordance with the classification recommended by the Association of Rheumatologists of Ukraine (2002). According to the ACR classification criteria, the disease activity was divided in the following way: I degree $-28.9 \%$ (11 patients); II degree - 50\% (19 patients); III degree - $23 \%$ ( 8 patients). 25 patients $(65,8 \%)$ were in the acute stage, among them $7(63,6 \%)$ - with the first degree of activity, $14(73,6)$ - with the II degree of activity, and $5(55 \%)$ - with the III degree of activity. 13 patients $(34,2 \%)$ were in the stage of remission. The average age of the patients was $34 \pm 9,8$, and the average length of the disease was 5-8 years. Number of women and men was $34(89,5 \%)$ and $4(10,5 \%)$, respectively. All patients were tested on the presence of LE-cells, ANA-autoantibodies and anti-dsDNA auto-AB.

\subsection{Blood Serum Preparation}

All blood samples were collected and utilized under approved protocols of the Institutional Review Board and with the informed consent. Blood samples were withdrawn using sterile conditions and allowed to clot at room temperature for minimum $10 \mathrm{~min}$. Blood serum was isolated by centrifugation at $4000 \mathrm{rpm}$ for $10 \mathrm{~min}$, divided among several vials, and kept at $-20^{\circ} \mathrm{C}$ until use.

\subsection{Antibody Purification}

Isolation of $\mathrm{IgG}$ from blood serum was performed, as described earlier [17]. $2 \mathrm{ml}$ of blood serum were precipitated with ammonium sulfate (50\% saturation). The pellet was dissolved in $0.15 \mathrm{M} \mathrm{NaCl}, 20 \mathrm{mM}$ Tris- $\mathrm{HCl}, \mathrm{pH}$ 7.5 and dialyzed against the same buffer. Then, IgGs were purified by chromatography on protein G-Sepharose and eluted from the column with $0,1 \mathrm{M} \mathrm{Glu-HCl}$, pH 2,6 and immediately neutralized with $1.5 \mathrm{M}$ Tris- $\mathrm{HCl}$, $\mathrm{pH}$ 8.8. AB was dialyzed against $20 \mathrm{mM}$ Tris- $\mathrm{HCl}$ buffer,
$\mathrm{pH} 7.5$ for 18 hours. Protein concentration was measureed on the NanoDrop ND 1000 spectrophotometer (NanoDrop Technologies, USA) using extinction coefficient of $\mathrm{IgG}$, preloaded in the device and the AB were tested for the proteolytic activity.

\subsection{Proteolytic Activity Assay}

Protease activity of IgG preparations was tested as described [17]. Commercial bovine basic protein (Sigma, USA) and calf thymus histone H1 (Axxora, Germany) were used as substrates for proteolysis. The hydrolysis reaction lasted 3 hours at $37^{\circ} \mathrm{C}$ in $20 \mu$ of the incubation

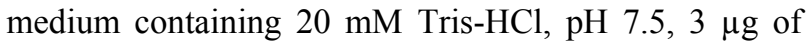
$\mathrm{AB}$ and $5 \mu \mathrm{g}$ of protein. The reaction was stopped by adding $5 \mu \mathrm{l}$ of denaturing buffer $(0.2 \mathrm{M}$ Tris- $\mathrm{HCl}, \mathrm{pH}$ 6.8, 4\% Ds-Na, 8\% 2-mercaptoethanol, 20\% glycerol). The reaction mixture was heated at $100^{\circ} \mathrm{C}$ for $3 \mathrm{~min}$ and hydrolysis products were separated by electrophoresis in $12 \%$ PAGE in the presence of $0.1 \%$ Ds-Na [18]. The gels were stained with Coomassie G-250. Quantitative analysis was done by using Gel-Pro program.

\section{RESULTS AND DISCUSSION}

Recently, we have revealed a novel hydrolytic activity of the IgG-antibodies towards histone H1 and MBP in blood serum of patients with clinically diagnosed SLE [14, 17]. At the same time, proteolytic activity was absent in the sera-derived antibodies of 18 healthy donors under control [17]. IgGs were isolated by chromatography on Protein G-Sepharose, and 4 of 10 SLE patients were found to possess IgGs that were capable of cleaving both histone H1 and MBP. Such activity was confirmed to be an intrinsic property of the $\mathrm{IgG}$ molecule, since it was preserved after gel filtration at alkaline and acidic $\mathrm{pH}$. From the proteolytically active IgG preparations by the affinity chromatography on histone $\mathrm{H} 1$-Sepharose were purified anti-histone IgGs and have shown they capability of hydrolyzing histone H1 and MBP. Summarizing, we have shown an existence in blood serum of SLE patients of anti-histone $\mathrm{H} 1 \mathrm{IgGs}$ with previously unknown proteolytic activity towards both histone $\mathrm{H} 1$ and MBP [17]. We suggest that these protelytically active AB could be associated with specific disorders appearing in SLE patients. To clarify this suggestion, 38 patients with different SLE severity were inquired. IgGs were purified by chromatography on the Protein G-Sepharose column and assayed for proteolytical activity towards histone $\mathrm{H} 1$ and MBP. Typical data of such assay are present on Figure 1, and also summarized in Table $\mathbf{1}$ and Table 2. It was found that 15 of $38 \mathrm{IgG}$ preparations obtained from SLE patients are capable of hydrolyzing histone $\mathrm{H} 1$ and MBP with different efficiency. 10 of 15 protease active IgG 


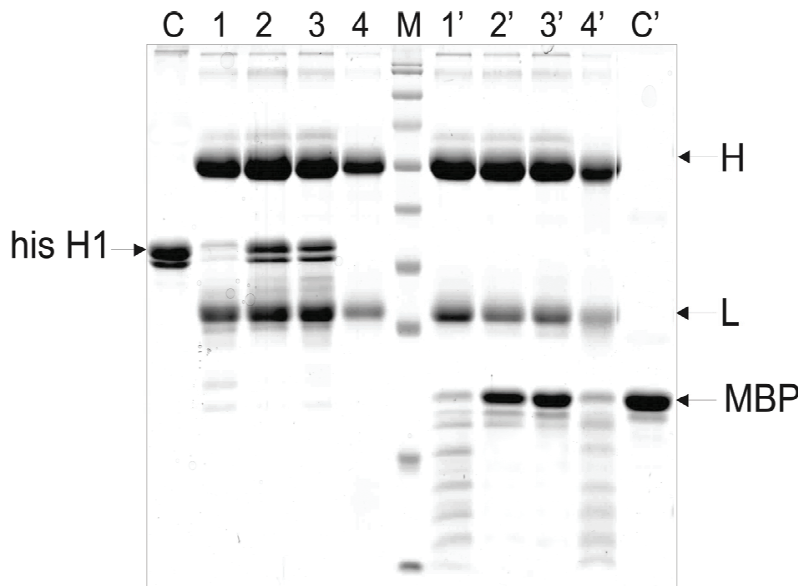

Figure 1. Proteolytic activity of polyclonal IgGs preparations, purified by chromatography on Protein G-sepharose from blood serum of SLE patients. Lines 1-4 - IgG preparations incubated with histone $\mathrm{H} 1$; Lines 1'-4' - IgGs preparations incubated with bMBP. C-histone $\mathrm{H} 1$ before incubation with IgGs (control). C' - bMBP before incubation with IgGs (control). Position of heavy $(\mathrm{H})$ and light $(\mathrm{L})$ chains of $\mathrm{IgG}$, and also position of histone $\mathrm{H} 1$ (his $\mathrm{H} 1$ ) and bovine myeline basic protein (bMBP) are shown by arrows. $\mathrm{M}$ - protein molecular mass markers $(17,34,43,55,72,95,130,170 \mathrm{kDa}$, respectively).

Table 2. Correlation between disease severities and proteolytic activity of IgGs.

\begin{tabular}{clrc}
\hline $\begin{array}{c}\text { Disease } \\
\text { activity }\end{array}$ & \multicolumn{2}{c}{ Stage of disease } & $\begin{array}{c}\text { Histone H1/MBP - } \\
\text { hydrolyzing activity }\end{array}$ \\
\hline \multirow{2}{*}{ I } & Acute & $7(63.3 \%)$ & $4(57.1 \%)$ \\
& Remission & $4(36.7 \%)$ & $1(25 \%)$ \\
\multirow{2}{*}{ II } & Acute & $14(73.6 \%)$ & $8(57.1 \%)$ \\
& Remission & $5(26.4 \%)$ & 0 \\
III & Acute & $4(50 \%)$ & $2(50 \%)$ \\
& Remission & $4(50 \%)$ & 0 \\
\hline
\end{tabular}

preparations hydrolyzed both histone $\mathrm{H} 1$ and MBP, 3 preparations were capable of cleaving only histone $\mathrm{H} 1$ and 2 of them - only MBP. Protease activity assay revealed that $\mathrm{AB}$ of 3 of 10 patients with diagnosed SLE disease for the first time was capable of cleaving only histone H1. None of 10 seropositive (ANA + dsDNA +) systematically treated SLE patients for year possessed of IgG with catalytical activity. Among 25 patients in acute stage of the disease, 2 showed a hydrolysing activity only towards histone $\mathrm{H} 1 ; 1$ patient (age 23) possessed a low activity towards MBP, and IgGs of 12 patients were capable of effectively cleaving both proteins. IgG preparation purified from blood serum of 6 patients with nervous system affection (headache or sleep disturbance) showed high catalytic activity towards both histone H1 and MBP proteins. Among 6 children of the puberty pe-
Table 1. Demographical and clinical characteristics of SLE patients.

\begin{tabular}{lll}
\hline \multicolumn{1}{c}{ Parameters } & $\mathrm{M} \pm \mathrm{SD}$ & $\begin{array}{c}\text { Proteolytical } \\
\text { activity of IgG }\end{array}$ \\
\hline $\begin{array}{l}\text { Gender: } \\
\text { Woman: }\end{array}$ & $\begin{array}{l}34(89.5 \%) \\
\text { Men: }\end{array}$ & $\mathrm{H}(3) ; \mathrm{M}(1) ; \mathrm{HM}(10)$ \\
\hline $\begin{array}{l}\text { Disease activity: } \\
\text { I degree }\end{array}$ & $11(28,9 \%)$ & $\mathrm{H}(3) ; \mathrm{M}(1) ; \mathrm{HM}(1)$ \\
II degree & $19(50 \%)$ & $\mathrm{H}(1) ; \mathrm{M}(0) ; \mathrm{HM}(7)$ \\
III degree & $8(21.1 \%)$ & $\mathrm{H}(0) ; \mathrm{M}(0) ; \mathrm{HM}(2)$ \\
\hline $\begin{array}{l}\text { Clinical features: } \\
\text { Joints affection (arthralgia) }\end{array}$ & $26(68.4 \%)$ & $\mathrm{H}(3) ; \mathrm{M}(2) ; \mathrm{HM}(9)$ \\
$\begin{array}{l}\text { Skin affection (erythema “butterfly") } \\
\text { nervous system affection: }\end{array}$ & $23(60.5 \%)$ & $\mathrm{H}(3) ; \mathrm{M}(2) ; \mathrm{HM}(6)$ \\
a) headache & $12(31.5 \%)$ & $\mathrm{H}(0) ; \mathrm{M}(0) ; \mathrm{HM}(6)$ \\
$\begin{array}{l}\text { 6) epileptic seizures } \\
\text { B) sleep disturbance }\end{array}$ & $1(0.026 \%)$ & $\mathrm{H}(0) ; \mathrm{M}(0) ; \mathrm{HM}(0)$ \\
Heart affection (carditis) & $4(10.5 \%)$ & $\mathrm{H}(0) ; \mathrm{M}(0) ; \mathrm{HM}(5)$ \\
Nephritis & $4(10.5 \%)$ & $\mathrm{H}(0) ; \mathrm{M}(0) ; \mathrm{HM}(5)$ \\
Active Epstein-Barr viruses infection & $5(13.1 \%)$ & $\mathrm{H}(0) ; \mathrm{M}(0) ; \mathrm{HM}(2)$ \\
Body temperature increase & $19(50 \%)$ & $\mathrm{H}(2) ; \mathrm{M}(0) ; \mathrm{HM}(9)$ \\
\hline
\end{tabular}

$\mathrm{H}, \mathrm{M}, \mathrm{HM}$ - proteolytic activity of IgGs towards histone H1, myelin basic protein, and both histone $\mathrm{H} 1$ and myelin basic protein, respectively. In brackets are shown a number of patients.

riod (age 13-16) suffering from SLE, 4 were in the acute stage and contained IgG-antibodies capable of hydrolyzing both histone $\mathrm{H} 1$ and MBP. The catalytic activity was not observed in 12 patients in the remission stage as well as in 3 patients with other systematic disoders (ankylosing spondylitis, systemic vasculitis, mixed disorder of the conjuctive tissue).

\section{CONCLUSIONS}

Appearance of proteolytic activity of IgG in blood serum of SLE patients towards both histone $\mathrm{H} 1$ and myelin basic protein tightly correlates with the disease severity in these patients.

\section{REFERENCES}

[1] Cervera, R., Khamashta, M.A., Font, J., Sebastiani, G.D., Gil, A., Lavilla, P., Mejía, J.C., Aydintug, A.O., Chwalinska-Sadowska, H., de Ramón, E., Fernández-Nebro, A., Galeazzi, M., Valen, M., Mathieu, A., Houssiau, F., Caro, N., Alba, P., Ramos-Casals, M., Ingelmo, M. and Hughes, G.R. (2003) European working party on systemic lupus erythematosus. Morbidity and mortality in systemic lupus erythematosus during a 10 -year period. A comparison of early and late matifestation in a cohort of 1, 000 patients. Medicine (Baltimore), 82(5), 299-308.

[2] Uramoto, K.M., Michet, C.J., Thumboo, J. Sunku, J., O'Fallon, W.N. and Gabriel, S.E. (1999) Trends in the incidence and mortality of systemic lupus erytemathosus, 
1950-1992. Arthritis \& Rheumatism, 42(1), 46-50.

[3] Pons-Estel, B.A., Catoggio, L.J., Cardiel, M.H., Soriano, E.R., Gentiletti, S., Villa, A.R., Abadi, I., Caeiro, F., Alvarellos, A. and Alarcón-Segovia, D. (2004) Grupo latinoamericano de estudio del lupus. The GLADEL multinational Latin American prospective inception cohort of 1,214 patients with systemic lupus erythematosus: Ethnic and disease heterogeneity among 'Hispanics', Medicine (Baltimore), 83(1), 1-17.

[4] Boddaert, J., Huong, D.L., Amoura, Z., Wechsler, B., Godeau, P. and Piette, J.C. (2003) Late-onset systemic lupus erythematosus. A personal series of 4 patients and pooled analisis of 714 cases in the literature. Medicine (Baltimore), 83(6), 348-359.

[5] Karlson, E.W., Daltroy, L.H., Lew, R.A., Wright, E.A., Partridge, A.J., Fossel, A.H., Roberts, W.N., Stern, S.H., Straaton, K.V., Wacholtz, M.C., Kavanaugh, A.F., Grosflam, J.M. and Liang, M.H. (1997) The relationship of socioeconomic status, race, and modifiable risk factors to outcomes in patients with systemic lupus erythematosus. Arthritis \& Rheumatism, 40(1), 47-56.

[6] To, C.H., Mok, C.C., Tang, S.S., Ying, S.K., Wong, R.W. and Lau, C.S. (2009) Prognostically distinct clinical patterns of systemic lupus erythematosus identified by cluster analysis. Lupus, 18(14), 1267-1275.

[7] Bach, J.F., Koutouzow, S. and van Endert, P.M. (1998) Are there unigue autoantigents triggering autoimmune diseases? Immunological Reviews, 164(1), 139-155.

[8] Kurien, B.T. and Scofield, R.H. (2006) Autoantibody determination in the diagnosis of systemic lupus erythematosus. Scandinavian Journal of Immunology, 64(3), 227-235.

[9] Nezlin, R., Alarcyn-Segovia, D. and Shoenfeld, Y. (1998) Immuno-chemical determination of DNA in immune complexes present in the circulation of patients with systemic lupus erythematosus. Journal of Autoimmunity, 11(5), 489-493.

[10] Schett, G., Smole, J., Zimmermann, C., Hiesberger, H., Hoefler, E., Fournel, S., Muller, S., Rubin, R.L. and
Steiner, G. (2002) The autoimmune response to chromatin antigens in systemic lupus erythematosus: Autoantibodies against histone $\mathrm{H} 1$ are a highly specific marker for SLE associated with increased disease activity. Lupus, 11(11), 704-715.

[11] Gabibov, A.V. Ponomarenko, N.A., Tretyak, E.B., et al. (2006) Catalic autoantibodies in clinical autoimmunity and modern medicine. Autoimmunity Reviews, 5(5), 324-330.

[12] Gabibov, A.G., Kozyr, A.V., Kolesnikov, A.V. and Suchkov, S.V. (2000) Disease association and cytotoxic effects of DNA-hydrolyzing autoantibodies. Chemical Immunology, 77, 130-156.

[13] Kozyr, A.V. and Gabibov, A.G. (2009) DNA-hydrolyzing $\mathrm{AB}$ : is catalytic activity a clue for physiological significance? Autoimmunity, 42(4), 359-361.

[14] Kit, I., Mahorivs'ka, I.R., Havryliuk, A.M., Chhop'iak, V.V., Bilyı̌, R.O. and Stořka, R.S. (2009) Proteolytic activity of blood serum IgG in patients with systemic lupus erythematosis. Ukrainskii Biokhimicheskii Zhurnal, 81(3), $77-83$.

[15] Kit, Y.Y., Starykovich, M.A., Richter, V. A. and Stoika, R.S. (2008) Detection and characterization of IgG- and sIgA-Abzymes capable of hydrolyzing Histone H1. Biochemistry (Moscow), 73(8), 950-956.

[16] Magorivska, I., Bilyy, R., Shalay, O., Loginsky, V., Kit, Y. and Stoika, R. (2009) Blood serum immunoglobulings of patients with multiple myeloma are capable of hydrolizing histone H1. Experimental Oncology, 31(2), 97-101.

[17] Magorivska, I.B., Bilyy, R.O., Havrylyuk, A.M., Chop'yak, V.V., Stoika, R.S. and Kit, Y.Y. (2010) Anti-histone H1 IgGs from blood serum of systemic lupus erythematosus patients are capable of hydrolyzing histone $\mathrm{H} 1$ and myelin basic protein. Journal of Molecular Recognization, 23(5), 495-502.

[18] Laemmli, U.K. (1970) Cleavage of structural proteins during the assembly of the head of bacteriophage T4 Nature, 227(5259), 680-685.

\section{Appendix}

List of Abbreviations:

SLE - systemic lupus erythematosus; MBP - myelin basic protein; $\mathrm{AB}$ - antibodies; auto-AB - autoantibodies 